\title{
Factor Analysis of The Digital Economy In The Villages
}

\author{
Iwan Kurniawan $^{1}$, Budi Setiawan ${ }^{2}$ \\ Politeknik STIA LAN Bandung, Jl. Hayam Wuruk No.34-38 Bandung \\ \{iwan.kurniawan@poltek.stialanbandung.ac.id\}
}

\begin{abstract}
This study aims to describe the characteristics of economic growth in rural communities, determine significant factors, and provide alternatives to enhance economic growth through the digital economy. The research method used is quantitative using factor analysis and determination of the research locus and respondents using the Proportional Stratified Random Sampling technique. Data collection using questionnaires and interview and observation guidelines. The results of research conducted in three districts in Bandung Regency show that the Digital Economy formation model which previously consisted of 12 components can be reduced to only 4 factors in rural areas, namely the factors of community environmental conditions, communication processes, implementation of activities, and businessmen competence. The role that is considered influential and strategic for the development of the digital economy in rural areas is the all factor of formation in the digital economy. The competence of businessmen is indeed very diverse but business actors who want to learn to adapt to follow the development of digital technology will increase economic growth in their villages. Variable Discordance, Internet Networking, Immediacy, and Knowledge have a strong relationship to the four factors of the formation of the digital economy.
\end{abstract}

Keywords: factor analysis, digital economy, villages

\section{Introduction}

Digitalization has changed the way human beings think and behave, especially in the economic sector because business processes are faster, more efficient, and effective. The digital era offers new economic opportunities that were not seen before, through various creative ways based on digital services. The business model in transactions also moves quickly from conventional market systems to e-commerce platform markets, which no longer recognize regional boundaries for both producers and consumers.

During the last decade Indonesia is experiencing the slowest economic growth, but the growth of the e-commerce industry is actually accelerating in the country's economy. Ecommerce is one part of digital economic activities. It is quite possible that the e-commerce industry can become one of the backbones of the national economy [9]. The Governor of West Java said to bring the Digital Village program for the village community to be more productive. Digital villages do not only deal with the internet but also changes the way it trades, changes the way it communicates, maps potential, promotes village tourism through a digital ecosystem. Businesspeople in the village can trade online and be trained in e-commerce literacy. Trading of village produce will be cheap and practical with an easy application [10]. 
West Java Province has the potential to become a pilot project about economic development through digitalization because most of the villages are on average included in the category of developing villages. Some characteristics of developing villages have information technology facilities and infrastructure, and the community has access to knowledge and use of information technology [6]. Information about the concept of the digital economy described by Don Tapscott consists of 12 components. This component will be applied to entrepreneurs in the village so that it becomes very valuable information to determine and become a major factor in determining the strategy. Regarding this matter, it is necessary to identify the factors that important role based on the perception of businessman in the village. One statistical method that can be used to find out this is factor analysis.

Village government management is an interesting issue to research and find solutions to its problems because the strategy of the Village Government will be the spearhead and an important part in solving the problems of economic growth in the community by developing a digital economic system. With a large enough village fund and a good management mechanism, it is certainly a necessity for increased development by the local village government. Based on the explanation above, the researcher wants to be able to determine significant factors and describe the characteristics of economic growth in rural communities and provide alternatives to increase economic growth through the digital economy.

\section{Materials and Methods}

\subsection{Digital Economy}

The term New Economy did first appear in the United States. According to Kauffman and ITIF, New Economy is measured by a number of indicators which are grouped into five components, namely knowledge-based work, globalization, economic dynamism, transformation to digital economy, and technological innovation capacity [3]. A country is said to develop its Digital economy is characterized by increasingly growing business or trade transactions that utilize the Internet as a medium of communication, collaboration, and cooperative of inter-company or between individuals. This can be seen as how to the rise of new and old companies that plunge into e-business and e-commerce formats.

Some characteristics of Digital economy by DonTapscott:

a. Knowledge: Knowledge of villagers will spark innovations that are superior and competitive.

b. Digitization: All products or services will be marketed through digital marketing.

c. Virtualization: The things can change economic activity in the form of virtual.

d. Molecularization: Changes in physical form to non-physical media.

e. Internetworking: Build a network economy with internet facilities.

f. Disintermediation: Does not require intermediaries anymore in buying and selling activities (directly).

g. Convergence: The convergence of computational, communication, and content together form an interactive multimedia platform.

h. Innovation: Imagination and human creativity that can make an update or modification in economic activity.

i. Presumption: Between consumers and producers becomes unclear because it can be both in the digital economy.

j. Immediacy: Economic activity takes place at that moment. 
k. Globalization: There is no limit to the activity of economic transactions.

1. Discordance: Occurrence of gaps between IT users and non IT users [8].

\subsection{Factor Analysis}

The factor analysis is one of the statistical analyses used by the stasticians multivariate concept and introduced by Spearman (1904), and developed by Thurstone (1947), Thomson, (1951), Lawley (1940) and others [7]. Factor analysis is a multivariate analysis technique to analyze multiple inter-variables simultaneously with the aim of simplifying the form of corelation between variables into fewer factors than the variables observed.

A factor is a set of variables that refers to the original variables. Random vector $\mathrm{X}$ with $\mathrm{P}$ component have an average of $\boldsymbol{\mu}$ and covarians matrix $\boldsymbol{\Sigma}$. The factor modeling is formed in order for $\mathrm{X}$ to be linear and to depend on some unobservable random variable's ones i.e. $\mathbf{F}_{1}, \mathbf{F}_{2}$, ...., $\mathbf{F}_{\mathrm{m}}$ called a common factor and $\boldsymbol{p}$ varian sources from $\varepsilon_{1}, \varepsilon_{2}, \ldots, \varepsilon_{p}$ called errors.

In general, the factor analysis model is as follows [2]:

$$
\begin{gathered}
X_{1}-\mu_{1}=L_{11} F_{1}+L_{12} F_{2}+\ldots+L_{1 m} F_{m}+\varepsilon_{1} \\
X_{2}-\mu_{2}=L_{21} F_{1}+L_{22} F_{2}+\ldots+L_{2 m} F_{m}+\varepsilon_{2} \\
\vdots \\
X_{p}-\mu_{p}=L_{p 1} F_{1}+L_{p 2} F_{2}+\ldots+L_{p m} F_{m}+\varepsilon_{p}
\end{gathered}
$$

or in a matrix form to:

$$
(X-\mu)_{p \times l}=L_{p \times m} F_{m \times l}+\varepsilon_{p \times l}
$$

description:

$X_{i}$ : A random vector that has $\mathrm{p}$ components on the observation to-i with $\mathrm{i}=1,2, \ldots, \mathrm{p}$

$\mu_{i}$ : The mourning of the Peubah to-i

$L_{i j}$ : Loading factors from the variables to-i and the factors to-j

$F_{j}$ : The j common factor

$\varepsilon_{i}$ : Errors from the variables to-i

\subsection{Factor Analysis Assumptions}

The main principle in the factor analysis is the correlation, so that of the following assumptions [4]:

a. The correlation of the inter-variables must be strong.

This can be identified by conducting a Barlet's Test to see if the correlation matrix used is an identity matrix or not. An identity matrix will have a value of determinant of one, meaning that inter-variables is not interconnected because the identity matrix has an element on the diagonal is one scores, while the other element is zero scores. Hypotheses tested in Barlett's Test are as follows:

Value Test Barlett $=-\ln |R|\left[n-1-\frac{(2 p+5)}{6}\right]$

Description:

$|R| \quad$ : Value of determinant

$\mathrm{N} \quad$ : Number of data

$\mathrm{P} \quad$ : Number of variables

The rule of decision for rejection of $\mathrm{H}_{0}$ is [4]:

$>$ Test Barlett Value $>\chi^{2}(\alpha ;(1 / 2) \mathrm{p}(\mathrm{p}-1))$ or 
$p$ value $\leq \alpha$ value

If the rule is being fulfilled then the matrix of correlation that tested is not an identity matrix, meaning there is a correlation or interconnected variables.

b. The index comparison distance between the correlation coefficient with the partial coefficient as a whole should approach the value 1 . It can be identified by the value of KaiserMayer-Olkin (KMO). KMO is an index of the distance comparison between the correlation coefficient and its partial correlation coefficient. If the number of squares of the partial correlation coefficient between the entire pair of variables is small compared to the number of quadratic correlation coefficient, then the KMO value will approach the value 1 . A small value of $\mathrm{KMO}$ indicates that the factor analysis is not appropriate for use. The KMO value is stated enough when greater than 0.5 [4]

\subsection{Parameter estimation}

The method used in the parameters estimations in this research is the principal component method. This method is used to calculate the value of a loading factor, which is the value of a variables contribution weight that will determine the position of a particular factor.

The main component of factor analysis from the matrix correlation that size $\mathrm{p} x \mathrm{p}$ has a eigen value and eigen vector as follows:

$$
\left(\hat{\lambda}_{1} \hat{v}_{1}\right),\left(\hat{\lambda}_{2} \hat{v}_{2}\right), \ldots,\left(\hat{\lambda}_{p} \hat{v}_{p}\right)
$$

With $\hat{\lambda}_{1} \geq \hat{\lambda}_{2} \geq \hat{\lambda}_{3}, \ldots, \hat{\lambda}_{p} \geq 0$ and $\mathrm{m}<\mathrm{p}$, where $\mathrm{m}$ is the number of factors used and $\mathrm{p}$ is many of the observed Peubah while the weight-scoring matrix of factors is written as follows:

$$
\hat{L}=\left[\sqrt{\hat{\lambda}_{1}} \hat{v}_{1}\left|\sqrt{\hat{\lambda}_{2}} \hat{v}_{2}\right| \ldots\left|\sqrt{\hat{\lambda}_{m-1}} \hat{v}_{m-1}\right| \sqrt{\hat{\lambda}_{m}} \hat{v}_{m}\right]
$$

The estimator of variation is derived from the following matrix:

$$
\hat{\psi}=\left[\begin{array}{cccc}
1-h_{1}{ }^{2} & 0 & \ldots & o \\
0 & 1-h_{2}^{2} & \ldots & 0 \\
0 & 0 & \ldots & \\
0 & 0 & \ldots & 1-h_{p}{ }^{2}
\end{array}\right]
$$

With $h_{i}{ }^{2}=\sum_{j=1}^{m} \hat{l}_{i j}{ }^{2}$ and the approach to the new $\mathrm{R}$ correlation matrix is the $\mathrm{R} * \approx \hat{L} \hat{L}^{\prime}+\hat{\psi}$.

To validate the model, before accepting the $\hat{L}$ and $\hat{\psi}$ as the last estimator needs to calculate the residual matrix:

$$
\text { Res }=|R-R *|
$$

If $\operatorname{Res} \approx 0$ then $\hat{L}$ and $\hat{\psi}$ can be considered quite good and acceptable [2]. The model can be said to be good if the residual value between the new correlation coefficient with the original correlation coefficient that is less than 0.05 has a percentage of more than $50 \%$ [4].

\subsection{Determination Number of Factors}

Some methods can be done in determining the number of factors to be used in the next analysis as follows:

a. The cumulative proportion $\mathrm{n}$ eigen value more than $75 \%$ [5]. 
b. The cumulative proportion $\mathrm{n}$ fruit roots feature more than $80 \%$ [2].

c. The number of eigen values are greater than one. This output can also go through the eigen value plot. This plot displays the eigen value of the matrix correlation $\mathrm{k}, \mathrm{k}=1,2, \ldots, \mathrm{p}$. With this chart, the number of factors selected such that the value of the roots of the characteristic more than one [4].

\subsection{Rotation factor}

The result of the factor analysis is a matrix of factors containing the weight coefficient of contributing a variable to the loading factor. Often the resulting output is difficult to interpret because a one variable can be correlated with several factors [4]. To make it easier for this, a factor rotation is carried out so that the previously complex factor matrix becomes simpler and easier to interpret. If the $\widehat{L}$ is a matrix has ordo $\mathrm{p} \mathrm{x} \mathrm{m} \mathrm{which} \mathrm{is} \mathrm{the} \mathrm{estimation} \mathrm{of} \mathrm{the} \mathrm{loading}$ factor then $\hat{L}^{*}=\hat{L} T$ with $\mathrm{TT}^{\prime}=\mathrm{T}^{\prime} \mathrm{T}=\mathrm{I}$ with $\hat{L}^{*}$ is the loading factor matrix after rotation and $\mathrm{T}$ is the transformation matrix. Some of the rotations that can be used for matrix-weighted factor transformation are orthogonal rotation (Varimax, Quartimax, Equimax), and oblique rotation (Promax, procusstes, and Harris-Kaiser) [2].

\subsection{Research methods}

The data in this study is quantitative data. The data source is obtained from the results of the filling of digital economy questionnaire by business actors in Bandung Regency. The sampling technique used proportional stratified random sampling. Several stages of problem solving in this study are as follows:

1. Description of Respondent characteristics

2. Analysis factor consist of:

a) A test of KMO and Barlett's Test of Sphericity.

b) Seeing Anti Image Matrices to all of variables

c) Extraction factors by communallities..

d) The process of rotation of factors against the factors that have been formed by Varimax method.

e) Interpretationof factors that have formed.

3. Interpretation of results.

\section{Results and Discussion}

\subsection{Respondents Characteristic}

Based on the results of data collection using questionnaire obtained characteristic of respondent and other information as shown in table 2 as follows:

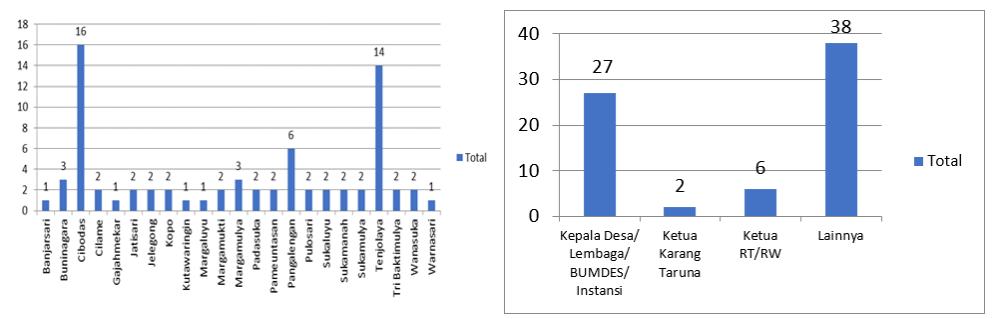

Fig 1. Villages of the respondent and Respondent Position 
The total respondents lived in several different villages, which are as many as 23 villages from 3 sub-districts (Pangalengan, Pasirjambu and Kutawaringin). Based on the Figure 1 can be found that the number of respondents in the institution research is most from Cibodas village 16 people and then came from Tenjolaya village as much as 14 people, then come from the village Pangalengan as many as 6 respondents. At least the respondents came from Banjarsari village, Gajahmekar Village, Kutawarwants Village, Margaluyu Village, and Warnasari village respectively, as many as 1 respondent.

In this study respondents came from a variety of professions (see Figure 2) that most of the respondents are other professions that totaled 38, second most people as the head of village/institution/BUMDESA/agency as many as 27 people after that the respondent who was a chairman of RT/RW 6 respondents. For respondents at least as chairman of Karang Taruna and village staff, each of the two respondents.
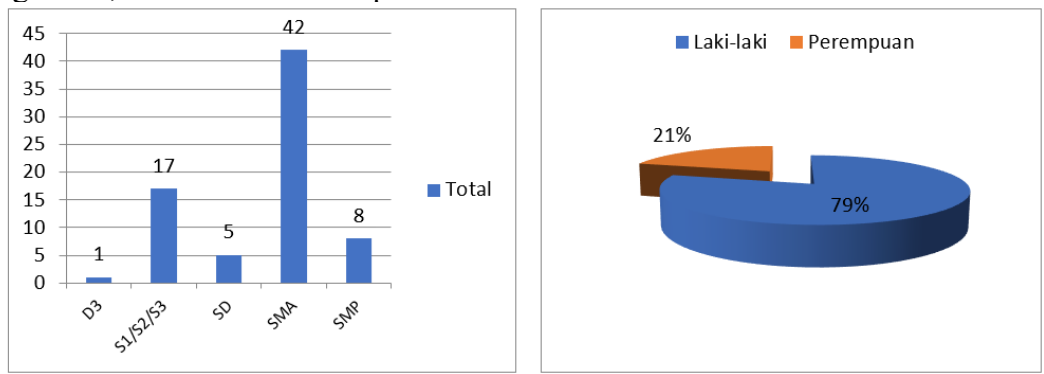

Fig 2. Last Education and Gender

The bar chart Figure 3 shows the data that the respondents in this study came from various educational backgrounds, of which 42 respondents were from high school (SMA) level, then the second most was the respondent with educational background S1/S2/S3 (Strata 1/Strata 2/Strata 3) as much as 17 people. There are still respondents from junior high School (SMP).

Table 1. Anti-image Matrices

\begin{tabular}{|c|c|c|c|c|c|c|c|c|c|c|c|c|c|}
\hline & & $\mathrm{X} 1$ & $\mathrm{X} 2$ & $\mathrm{X} 3$ & $\mathrm{X} 4$ & $\mathrm{X} 5$ & $\mathrm{X} 6$ & $\mathrm{X} 7$ & $\mathrm{X} 8$ & $\mathrm{X} 9$ & $\mathrm{X} 10$ & $\mathrm{X} 11$ & $\mathrm{X} 12$ \\
\hline Anti-image & $\mathrm{X} 1$ &, 818 &,- 196 &,- 095 &,- 016 &,- 003 &,- 081 & .084 &, 113 &,- 040 &,- 097 &,- 134 &, 023 \\
\hline \multirow{11}{*}{ Covariance } & $\mathrm{x} 2$ &,- 196 &, 709 &, 004 &,- 059 &,- 159 &,- 132 &, 049 &,- 012 &,- 073 &, 140 & 098 &,- 008 \\
\hline & $\mathrm{X} 3$ &,- 095 & .004 & ,678 &,- 206 &, 051 &, 052 &, 082 &, 004 &,- 067 & ,063 &, 090 &,- 183 \\
\hline & $\mathrm{X} 4$ &,- 016 &,- 059 &,- 206 &, 567 &,- 080 &, 057 &,- 138 &,- 032 &,- 038 &,- 017 &,- 037 &,- 026 \\
\hline & $\mathrm{X} 5$ &,- 003 &,- 159 &, 051 &,- 080 & ,439 &,- 069 &,- 196 &,- 119 & 093 &,- 063 &,- 044 &, 045 \\
\hline & $\mathrm{X} 6$ &,- 081 &,- 132 &, 052 &, 057 &,- 069 & ,693 &,- 102 &,- 109 &,- 026 &, 019 &, 002 &,- 014 \\
\hline & $\mathrm{X} 7$ & ,084 & ,049 & ,082 &,- 138 &,- 196 &,- 102 &, 448 & ,108 &,- 088 &,- 015 &,- 027 &,- 105 \\
\hline & $\mathrm{X} 8$ & ,113 &,- 012 &, 004 &,- 032 &,- 119 &,- 109 &, 108 &, 483 &,- 180 &,- 148 &,- 144 & ,079 \\
\hline & $\mathrm{X} 9$ &,- 040 &,- 073 &,- 067 &,- 038 & ,093 &,- 026 &,- 088 &,- 180 &, 516 &,- 176 &, 070 &,- 111 \\
\hline & $\mathrm{X} 10$ &,- 097 &, 140 & ,063 &,- 017 &,- 063 &, 019 &,- 015 &,- 148 &,- 176 &, 598 &,- 004 & 016 \\
\hline & X11 &,- 134 &, 098 & ,090 &,- 037 &,- 044 &, 002 &,- 027 &,- 144 &, 070 &,- 004 &, 533 &,- 255 \\
\hline & $\mathrm{X} 12$ &, 023 &,- 008 &,- 183 &,- 026 &, 045 &,- 014 &,- 105 &, 079 &,- 111 &, 016 &,- 255 & .478 \\
\hline \multirow{12}{*}{$\begin{array}{l}\text { Anti-image } \\
\text { Correlation }\end{array}$} & $\mathrm{X} 1$ &, $525 \mathrm{a}$ &,- 257 &,- 128 &,- 023 &,- 005 &,- 108 &, 139 &, 180 &,- 062 &,- 139 &,- 202 &, 037 \\
\hline & $\mathrm{x} 2$ &,- 257 &, $602 a$ &, 005 &,- 093 &,- 286 &,- 189 &, 086 &,- 020 &,- 121 &, 215 &, 159 &,- 013 \\
\hline & $\mathrm{X} 3$ &,- 128 &, 005 &, $531 \mathrm{a}$ &,- 331 & ,094 &, 076 &, 148 &, 007 &,- 113 & ,099 &, 150 &,- 321 \\
\hline & $\mathrm{X} 4$ &,- 023 &,- 093 &,- 331 &, $828 \mathrm{a}$ &,- 159 & ,091 &,- 273 &,- 062 &,- 069 &,- 028 &,- 068 &,- 050 \\
\hline & X5 &,- 005 &,- 286 &, 094 &,- 159 &, $744 a$ &,- 124 &,- 442 &,- 258 & , 195 &,- 124 &,- 092 & ,097 \\
\hline & $\mathrm{X} 6$ &,- 108 &,- 189 & ,076 & ,091 &,- 124 & ,844a &,- 182 &,- 189 &,- 043 &, 030 &, 003 &,- 025 \\
\hline & $\mathrm{X} 7$ & 139 & ,086 & 148 &,- 273 &,- 442 &,- 182 &, $728 \mathrm{a}$ & ,233 &,- 183 &,- 029 &,- 055 &,- 226 \\
\hline & $\mathrm{X} 8$ & , 180 &,- 020 & ,007 &,- 062 &,- 258 & -189 &, 233 & ,692a &,- 361 &,- 275 &,- 285 & ,165 \\
\hline & $\mathrm{X} 9$ &,- 062 &,- 121 &,- 113 &,- 069 & 195 &,- 043 &,- 183 &,- 361 &, $743 a$ &,- 316 & ,134 &,- 223 \\
\hline & $\mathrm{X} 10$ &,- 139 & 215 & ,099 &,- 028 &,- 124 &, 030 &,- 029 &,- 275 &,- 316 &, $770 a$ &,- 007 &, 030 \\
\hline & $\mathrm{X} 11$ &,- 202 & ,159 & ,150 &,- 068 &,- 092 &, 003 &,- 055 &,- 285 & ,134 &,- 007 & ,688a &,- 506 \\
\hline & $\mathrm{X} 12$ &, 037 &,- 013 &,- 321 &,- 050 &, 097 &,- 025 &,- 226 & , 165 &,- 223 &, 030 &,- 506 &, $672 a$ \\
\hline
\end{tabular}


Level, 8 people and from elementary school (primary level), 5 people. Respondents at least from the education level of D3 (Diploma 3) are as much as 1 person. The pie chart Figure 4 shows that most gender of respondent came from man as much as $79 \%$ and $21 \%$ from woman.

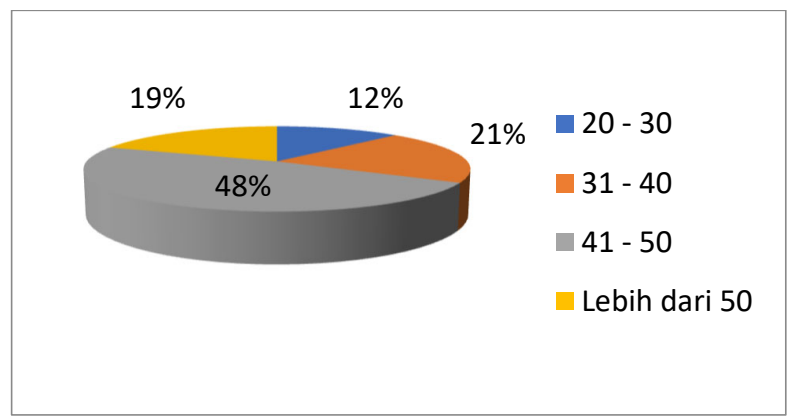

Fig 3. Respondent's Age

In the pie chart Figure. 5, it can be noted that respondents in this institutional research came from an variety of age ranges. Most respondents came from the age range from 41 to 50 years, i.e. as much as $48 \%$. The second most respondents came from the age range of 31-40 years as much as $21 \%$ and $>50$ years, i.e. as much as $19 \%$. Respondents were at least $20-30$ years of age in $12 \%$.

\subsection{Factor analysis}

The first step in the factor analysis is to use the Kaiser Meyer Olkin Measure of Sampling Adequacy (KMO MSA) value against the correlation of the research variables. The KMO value indicates good or not of data obtained for further analysis. Interpretation of the value of the $\mathrm{KMO}$ when between 0.5-1 then the data is good to be analyzed further and the value of KMO is smaller than 0.5 then it is not good to be analyzed further [1].

Table 1. KMO and Barlett's Test

\begin{tabular}{lll}
\hline \multicolumn{2}{l}{ Kaiser-Meyer-Olkin Measure of Sampling Adequacy. } & 0,717 \\
\hline \multirow{3}{*}{ Bartlett's Test of Sphericity } & Approx. Chi-Square & 262,569 \\
& df & 66 \\
& Sig. & 0,000 \\
\hline
\end{tabular}

After that, the second step is to look at the results in the Anti-image matrix Table 2. In the Anti-image matrices table there are Anti-Image Covariance and Anti-Image Correlation. The value that needs to be seen is the value marked 'a' in the Anti-Image Correlation section must be greater than 0.5 , if any variable does not meet the criteria, then the variable needs to be eliminated and must be retested.

Based on the results in the Anti Image Matrices table, there are no variables that need to be eliminated so that they can carry out the analysis to the next step. The third step in factor analysis is to look at the results from the Communalities table which consists of Initials and Extractions. The interpretation of the value is if there is a variable that has an extraction value of less than 0.5 then the variable must be eliminated and need to be retested starting from the first step in factor analysis. 
Table 3. Communalities

\begin{tabular}{lll}
\hline & Initial & Extraction \\
\hline X1 (Knowledge) & 1,000 & 0,580 \\
X2 (Digitization) & 1,000 & 0,730 \\
X3 (Virtualization) & 1,000 & 0,687 \\
X4 (Molecularization) & 1,000 & 0,574 \\
X5 (Internetworking) & 1,000 & 0,740 \\
X6 (Disintermediation) & 1,000 & 0,535 \\
X7 (Convergence) & 1,000 & 0,743 \\
X8 (Innovation) & 1,000 & 0,714 \\
X9 (Prosumption) & 1,000 & 0,669 \\
X10 (Immediacy) & 1,000 & 0,722 \\
X11 (Globalization) & 1,000 & 0,510 \\
X12 (Discordance) & 1,000 & 0,727 \\
\hline
\end{tabular}

Based on the test results in Table 3, the greatest extraction value is the variable of convergence (0.743), inter-network (0.74), and digitalization (0.730). The interpretation of this value is that 74.3 percent of the variable influence of convergence provides the greatest influence on digital economic development among the eleven other variables. The Figure 4 below shows that there are 4 components that have a eigen value of more than one. The Screeplot Image explains the relationship between the number of factors formed and the eigenvalue in graphical form.

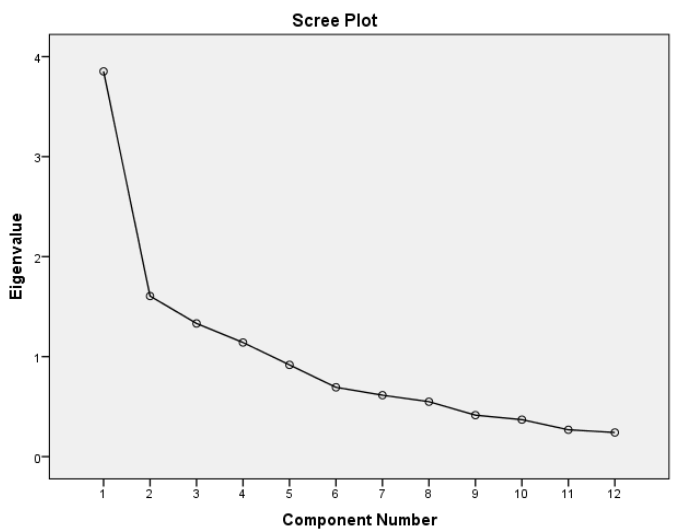

Fig 4. Scree Plot

In the Table 4 shows there are 4 factors that are formed from 12 variables entered. Each eigenvalue factor $>1$. Factor 1 eigen value of 3,853 with variance $(32,104 \%)$, Factor 2 eigenvalue of 1,606 with variance $(13,380 \%)$, Factor 3 eigenvalue of 1,332 with $(11,099 \%)$ and Factor 4 of eigenvalue of 1,141 with variance (9,511\%). Eigenvalue values describe the relative importance of each factor in calculating the variance of the 12 variables analyzed. The total variance if of the 12 variables extracted into 4 factors are: $32,104 \%+13,380 \%+11,099 \%+9,511 \%=66,094 \%$ 
Table 4. Total Variance Explained

\begin{tabular}{|c|c|c|c|c|c|c|c|c|c|}
\hline \multirow[b]{2}{*}{ Component } & \multicolumn{3}{|c|}{ Initial Eigenvalues } & \multicolumn{3}{|c|}{$\begin{array}{c}\text { Extraction Sums of Squared } \\
\text { Loadings }\end{array}$} & \multicolumn{3}{|c|}{$\begin{array}{c}\text { Rotation Sums of Squared } \\
\text { Loadings }\end{array}$} \\
\hline & Total & $\begin{array}{c}\% \text { of } \\
\text { Variance }\end{array}$ & $\begin{array}{c}\text { Cumulative } \\
\%\end{array}$ & Total & $\begin{array}{c}\% \text { of } \\
\text { Variance }\end{array}$ & $\begin{array}{c}\text { Cumulative } \\
\%\end{array}$ & Total & $\begin{array}{c}\% \text { of } \\
\text { Variance }\end{array}$ & $\begin{array}{c}\text { Cumulative } \\
\%\end{array}$ \\
\hline 1 & 3,853 & 32,104 & 32,104 & 3,853 & 32,104 & 32,104 & 2,354 & 19,616 & 19,616 \\
\hline 2 & 1,606 & 13,380 & 45,484 & 1,606 & 13,380 & 45,484 & 2,149 & 17,909 & 37,525 \\
\hline 3 & 1,332 & 11,099 & 56,583 & 1,332 & 11,099 & 56,583 & 2,065 & 17,204 & 54,729 \\
\hline 4 & 1,141 & 9,511 & 66,094 & 1,141 & 9,511 & 66,094 & 1,364 & 11,364 & 66,094 \\
\hline 5 & 0,918 & 7,646 & 73,739 & & & & & & \\
\hline 6 & 0,693 & 5,776 & 79,516 & & & & & & \\
\hline 7 & 0,614 & 5,119 & 84,634 & & & & & & \\
\hline 8 & 0,549 & 4,578 & 89,212 & & & & & & \\
\hline 9 & 0,415 & 3,459 & 92,671 & & & & & & \\
\hline 10 & 0,370 & 3,081 & 95,752 & & & & & & \\
\hline 11 & 0,268 & 2,236 & 97,989 & & & & & & \\
\hline 12 & 0,241 & 2,011 & 100,000 & & & & & & \\
\hline
\end{tabular}

The variables that are in each of the factors formed are determined based on the factor loading of the biggest factor of each variables to the specific factor. The loading factor will indicate the related level of a variables in of the factors formed. Based on the results of the analysis shows the loading factor is still somewhat difficult to classify the variable to the formed factor. Therefore, the rotation of factors is required by Varimax method.

The rotation results by using the Varimax method are shown in the table below:

Table 5. Rotated Component Matrix

\begin{tabular}{lllll}
\hline \multicolumn{1}{c}{ Component } & \multicolumn{5}{c}{ ( } & 2 & 3 & 4 \\
\hline X1 (Knowledge) & 0,084 & 0,002 & 0,109 & $\mathbf{0 , 7 4 9}$ \\
X2 (Digitization) & $-0,047$ & 0,525 & $-0,071$ & $\mathbf{0 , 6 6 9}$ \\
X3 (Virtualization) & $\mathbf{0 , 5 7 9}$ & $-0,403$ & $-0,038$ & 0,434 \\
X4 (Molecularization) & $\mathbf{0 , 6 6 0}$ & 0,291 & 0,146 & 0,181 \\
X5 (Internetworking) & 0,222 & $\mathbf{0 , 8 0 1}$ & 0,221 & 0,019 \\
X7 (Convergence) & 0,558 & $\mathbf{0 , 6 3 2}$ & 0,099 & $-0,149$ \\
X8 (Innovation) & 0,058 & 0,304 & $\mathbf{0 , 7 8 6}$ & 0,008 \\
X9 (Prosumption) & 0,350 & 0,051 & $\mathbf{0 , 7 0 4}$ & 0,220 \\
X10 (Immediacy) & 0,091 & 0,108 & $\mathbf{0 , 8 3 7}$ & $-0,040$ \\
X12 (Discordance) & $\mathbf{0 , 8 4 5}$ & 0,014 & 0,097 & 0,045 \\
X6 (Disintermediation) & 0,028 & $\mathbf{0 , 6 5 4}$ & 0,245 & 0,216 \\
X11 (Globalization) & $\mathbf{0 , 6 0 3}$ & 0,226 & 0,286 & $-0,117$ \\
\hline
\end{tabular}

Based on the results of the data in table 5, the variables on the first factor (dominant) start from the greatest of loading factors are Discordance (0.845), Molecularization (0.660), Globalization (0.603), and Virtualization (0.736). Second factor consists of Internetworking (0.801), Disintermediation (0.654), and Convergence (0.632). Third factor includes variables of Immediacy (0.837), Innovations (0.786), and Prosumption (0.704). Fourth factor includes variables of Knowledge (0.749) and Digitization (0.669). Variables already classified, have a strong correlation that makes up four factors. The factors are classified and given names according to the relation of each variable as in the table below. 
Table 6. Factor Formation in the Digital Economy

\begin{tabular}{llc}
\hline $\begin{array}{l}\text { Component } \\
\text { (Factor) }\end{array}$ & \multicolumn{1}{c}{ Variables } & Loading Factor \\
\hline First Factor : & Discordance & $\mathbf{0 , 8 4 5}$ \\
Community & Molecularization & 0,660 \\
Environmental & Globalization & 0,603 \\
Conditions & Virtualization & 0,736 \\
\hline Second Factor : & Internetworking & $\mathbf{0 , 8 0 1}$ \\
Communication & Disintermediation & 0,654 \\
Process & Convergence & 0,632 \\
\hline Third Factor : & Immediacy & $\mathbf{0 , 8 3 7}$ \\
Activity & Innovations & 0,786 \\
Implementation & Prosumption & 0,704 \\
\hline Fourth Factor : & Knowledge & $\mathbf{0 , 7 4 9}$ \\
Business Competency & Digitization & 0,669 \\
\hline
\end{tabular}

Each factor formed has each of its characteristic variables with their loading factor values. This means that the discordance variable has a strong correlation to the environmental conditions of the community, Internetworking has a strong correlation with the communication process, immediacy has a strong correlation to the implementation of activities, and knowledge has a strong with business competence.

\section{Conclusions}

The results of developing the digital economy model and analyzing research data in the field relating to the role of the digital economy that is expected to contribute on a economy business in rural, there are some findings that researchers can be explain as follows:

a. Most of the characteristics of respondents (business) are from Cibodas and Tenjolaya, have varied positions besides the Head of Village / Institution / BUMDES / Institution and Head of RT / RW and Karang Taruna, high school education, male sex, and age $41-50$ years.

b. The model of digital economy formation that previously consisted of 12 components, so that what can be done specifically in the villages can be reduced to only 4 factors: Community Environmental Condition Factor, Communication Process Factors, Activity Implementation Factor, and Business Competency Factor.

c. Variable Discordance, Internetworking, Immediacy, and Knowledge have a strong relationship to the four factors of the formation of the digital economy.

\section{Acknowledgment}

We are grateful to Politeknik STIA LAN Bandung and the Institutional Research Team who have assisted and supported this digital economic research and respondents who have helped provide information related to digital economic developments in villages in the Pangalengan, Pasirjambu and Kutawaringin Districts. 


\section{References}

[1] Hair, Anderson, Tatham, Black. 1998. Multivariate Data Analysis, Fifth Edition, Prentice-Hall International., Inc.

[2] Johnson RA., Wichern DW. 2007. Applied Multivariate Statistical Analysis. 6th ed. New Jersey, USA : Prentice-Hall, Inc.

[3] Luthfiseftianafif. 2017. Digital Mobile Economy. Accessed from: http://luthfiseftianafif.blogspot.com/

[4] Suliyanto 2005. Analisis Data dalam Aplikasi Pemasaran. Bogor: Ghalia Indonesia.

[5] Morrison DF. 1978. Multivariate Statistical Methods. Iowa, USA: The Iowa State University Pr.

[6] Setiawan, Budi. Afandi, M.N. Kurniawan, I. 2019. Development Strategy if Village Government with Measurement of Village Building Index in Garut District. Proceeding Advances in Social Sciences, Eduction and Humanities Research (Atlantis Press), Vol 343.p 526-530.

[7] Sartono, B et al. 2003. Modul Teori: Analisis Peubah Ganda. Bogor: Departemen Statistika FMIPA, IPB.

[8] Munandar, Angga. 2018. Menyambut Era Ekonomi Digital Cryptocurrency. Accessed from: https://www.wattpad.com/story/152942686-menyambut-era-digitalcryptocurrency

[9] Kementrian Komunikasi dan Informatika. 2015. Indonesia Akan Jadi Pemain Ekonomi Digital Terbesar di Asia Tenggara Accessed from: https://kominfo.go.id/index.php/content/detail/6441/Indonesia\%2BAkan\%2BJadi\%2BPemain\%2B Ekonomi\%2BDigital\%2BTerbesar\%2Bdi\%2BAsia\%2BTenggara/0/berita_satker

[10] Tempo.co. 2018. Kembangkan Ekonomi Desa, BUMDes Rambah Ranah Digital. Accessed from: https://nasional.tempo.co/read/1086962/kembangkan-ekonomidesa-bumdes-rambah-ranahdigital/full\&view $=$ ok 